\title{
Effect of blind feeding during the first month of the culture cycle on growth of Penaeus monodon, Fabricius cultured in \\ semi-intensively managed ponds in the \\ North West of Sri Lanka
}

\author{
U. P. K. Epa \\ Department of Zoology and Environmental Management \\ Faculty of Science, University of Kelaniya, Sri Lanka \\ epa@kln.ac.lk
}

\begin{abstract}
The Initial feeding regime of cultured shrimp, Penaeus monodon, in many semiintensively managed farms in Sri Lanka is based on intuition. This study was conducted to evaluate feed management strategies employed during the first month of the culture cycle (the period of blind feeding) in five selected, semiintensively managed shrimp farms located in the North West of Sri Lanka; three earthen ponds $(0.3-0.5 \mathrm{ha})$ in each farm were selected. Feed types, the ration, the feeding frequency and the adjustments made to feeding regime in each farm were recorded weekly. The Mean body weight and the mean \% specific growth rate (\%SGR) of shrimp cultured in each farm were calculated after 30 days of culture cycle.
\end{abstract}

Blind feeding was implemented in all the farms from the date of stocking of shrimp post larvae up to the first 30 days of culture. The feed ration among farms varied significantly with a range of $4.0-7.3 \mathrm{~kg} /$ day/100,000 post larvae (Oneway ANOVA, $p<0.05)$. The farmers did not consider stocking densities of shrimp post larvae as an important factor when calculating the feed ration. A correlation was not found between the mean \%SGR of shrimp and the amounts offeed given during the blind feeding period (Pearson correlation, $R=-0.15 ; p=0.8$ ). The weight gain of shrimp also did not correlate with the amount of feed given during the period of blind feeding (Pearson correlation, $R=-0.33$; $p=0.6$ ). At the end of the blind period, the mean body weight and the mean \%SGR of shrimp at the end of the 
blind feeding period in selected farms varied from 2.0-3.3g and 2.6-3.9 day-1 respectively. The early life stages of shrimp may be more dependent on natural productivity of the pond environment for food rather than on formulated feed. Therefore, there is a possibility for reduction of the amount of given feed during the initial stages of the culture cycle without compromising the growth of shrimp post larvae.

Keywords: Penaeus monodon, blind feeding, \%SGR, stocking density

\section{Introduction}

Shrimp farming in Asia has been developed steadily over the last four decades in response to the increasing world market demand. At the same time, shrimp production systems of many countries changed from 'extensive' towards 'intensive' with increasing inputs of high quality feed and good water quality. Though farmers pay more attention to the nutritional quality and price of feed, on farm feed management is often neglected (Nunes, 2009; Tacon et al., 2013). On farm feed management techniques in tropical shrimp culture are mainly based on intuition. To a large extent, this is because most aquaculture research has been conducted in developed countries with temperate species (Nunes and Parsons, 1999).

Feeding strategies in shrimp culture range from the use of fertilizers and simple supplementary feed mixtures to water stable pelleted shrimp feeds (Tacon, 1993; Mohanty, 2001; Nunes, 2009). The aim of feed management at the farm level is to make available the best quality formulated feeds to the animals, in the required amounts at the right times and places (Akiyama \& Chwang, 1989; Jorry, 1995; Tacon et al., 2013). When feed arrives at the farm, methods of feed presentation, feeding rate and frequencies are the three main areas where much improvement can be made (Akiyama \& Chwang, 1989; Hasan, 2001). Improvements in feed consumption can be achieved by feeding at a time when it can be used most efficiently. For most of the cultured shrimp species, feeding tables relating to body size and ration size as well as recommendations on feeding methods are available (Kongkeo, 1997; Cruz, 1991; Hung \& Quy, 2013). However, the application of 
such recommendations are questionable at the early stages of the culture cycle as farmers cannot readily monitor the growth, survival and biomass of shrimp and their feed consumption. In addition, information on feed management often requires adjustments at each farm as conditions change from farm to farm. Feed demand cannot be readily estimated using feed monitoring trays during the first few weeks of culture cycle and therefore, available option for farmers is to practice blind feeding. Generally, pond water is not changed during the first month of the culture cycle.

According to De Silva and Davy (1992) the most appropriate approach to manage feed in aquaculture ponds would be to evaluate the current feeding practices and feeds offer rather than to develop new diets which are completely alien to farmers. This study was carried out to evaluate feed management strategies during the blind feeding period of the culture cycle in shrimp farms located in North Western Province of Sri Lanka with a view to suggest possible improvements.

\section{Methods and materials}

\section{Sampling sites}

Five commercial shrimp farms located in Thoduwawa, Madurankuliya and Palawi in the North West of Sri Lanka were selected for this study. The physical characteristics of the farms selected are given in Table 1.

Table 1. Physical characteristics of the selected shrimp farms (M1, T1, M2, T2 and P are selected farms)

\begin{tabular}{llllll}
\hline Character & M1 & T1 & M2 & T2 & P \\
\hline & Madurankuliya & Thoduwawa & Madurankuliya & Thoduwawa & Palawi \\
Water & Dutch canal & Dutch canal & Dutch canal & Dutch canal & $\begin{array}{l}\text { Puttalam } \\
\text { source }\end{array}$ \\
$\begin{array}{l}\text { Size (ha) } \\
\text { No. of }\end{array}$ & 10 & 28 & 12 & & lagoon \\
ponds & 12 & 18 & 16 & 1.5 & 8 \\
$\begin{array}{l}\text { No. } \\
\text { studied }\end{array}$ & 03 & 03 & 03 & 04 & 11 \\
& & & & 03 & 03
\end{tabular}

Contd. 


\begin{tabular}{|c|c|c|c|c|c|}
\hline $\begin{array}{l}\text { Pond size } \\
\text { (ha) }\end{array}$ & $0.4-0.5$ & $0.4-0.5$ & $0.4-0.5$ & $0.3-0.4$ & $0.3-0.5$ \\
\hline $\begin{array}{l}\text { Stocking } \\
\text { density } \\
\text { (post } \\
\text { larvae } \mathrm{m}^{-2} \text { ) }\end{array}$ & 25 & 20 & 30 & 15 & 24 \\
\hline $\begin{array}{l}\text { Age of pls at } \\
\text { stocking }\end{array}$ & 20 & 20 & 20 & 22 & 22 \\
\hline
\end{tabular}

Three rectangular, earthen ponds from each farm were randomly selected for this study. No attempt was made to interfere with the ongoing farming practices in the selected farms and the study was carried out from February to March, 2012.

\section{Farm management}

The ponds were fertilized with inorganic and organic manure before stocking of post larvae. In brief, $12-20 \mathrm{~kg} \mathrm{ha}^{-1}$ urea and $16 \mathrm{~kg} \mathrm{ha}^{-1}$ triple super phosphate were applied into the ponds. Cow dung and chicken manure at a rate of $250-300$ $\mathrm{kg} \mathrm{ha}^{-1}$ were applied to Farm T2. Each pond was stocked with P. monodon post larvae purchased from three commercial hatcheries. The pond sizes and stocking densities are given in Table 1.

The farms were weekly visited and all the feed management practices employed were recorded. The farm owners and managers were informed to record all day to day management procedures employed i.e. feed type, ration, feeding frequency, mode of application and other management measures such as addition of fertilizers. The shrimp were fed with a widely used, commercial pelleted feed. The percentage protein, lipid, ash and moisture levels in commercial shrimp feed were $42,9,12$ and 10, respectively.

\section{Shrimp growth and feed utilization}

After 30 days of stocking, the shrimp in all the experimental ponds were sampled using a cast net. Sampling was done in the late evening covering several points throughout the pond. In each pond, more than 200 shrimp were sampled and weighed using a portable balance (Model SK 1000, NAD). The average body weight of shrimp at each pond was calculated according to the following formula: 
Average body weight $=$ Weight of sampled shrimp $/$ number sampled. Data collected from three ponds of one farm were used to obtain mean body weight of shrimp for that particular farm. A computation reflecting the growth as percent of body weight were made using the specific growth rate as follows: percentage specific growth rate $(\% \mathrm{SGR})=\ln \mathrm{W}_{2}-\ln \mathrm{W}_{1} / \mathrm{t}_{2}-\mathrm{t}_{1} \times 100$, where $\mathrm{W}_{2}=$ average body weight at current sampling; $\mathrm{W}_{1}=$ average body weight at previous sampling ( $\mathrm{W}_{1}$ was considered as zero in this study); $\mathrm{t}_{1}=$ days of culture at previous sampling ( $t_{1}$ was considered as zero in this study); $t_{2}=$ days of culture at current sampling.

\section{Pond water quality}

The dissolved oxygen content (DO), $\mathrm{pH}$ value, salinity, turbidity and water temperature were weekly measured in situ using a water quality checker (Model WQC - 22A, TOA Electronics Ltd., Japan). Ammonia, nitrite, nitrate and total phosphorus levels (Parsons et al., 1984; APHA 1995) of experimental pond water were measured weekly at the laboratory.

\section{Results}

\section{Blind feeding}

The average weight increment of shrimp after the blind feeding period varied between 2.0 - 3.3g showing high variation in growth at the initial stages of the culture cycle in different farms (Figure 1). The highest and lowest average weights were recorded in the farm T1 (3.3g) and M1 (2.0g), respectively. 
Figure 1. Average weight \pm sd of shrimp in each selected farm after the blind feeding period

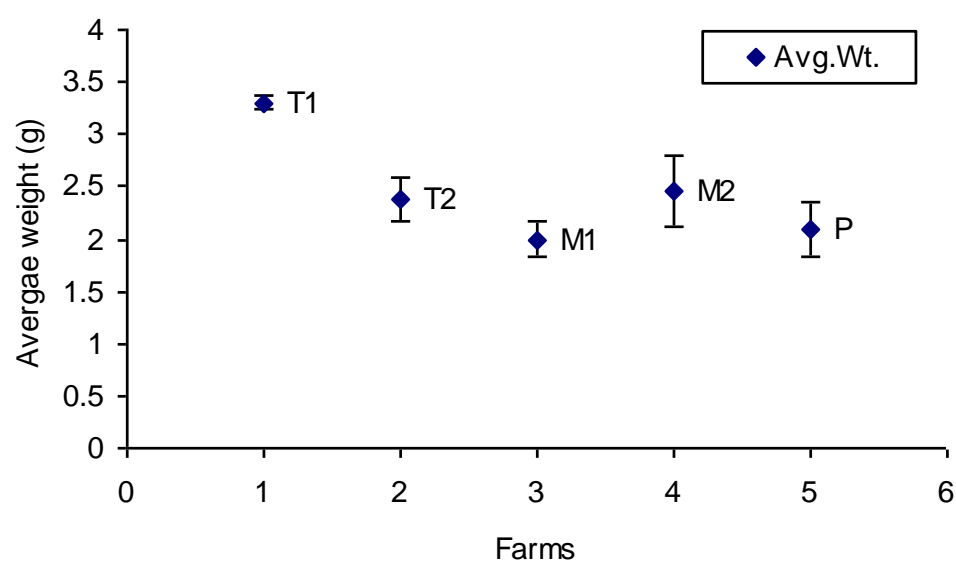

The blind feeding strategies considerably varied between farms (Table 2). Feed given at the first month of the culture cycle varied between $120.8-219.8 \mathrm{~kg}$ / 100000 post larvae. Farm $\mathrm{P}$ had the highest feeding rate $\left(7.9 \mathrm{kgday}^{-1}\right)$ while farm M2 had the lowest rate $\left(4.3 \mathrm{kgday}^{-1}\right)$ during the first month of the culture cycle (Figure 2). The post larvae reared in farms $\mathrm{T} 1$ and $\mathrm{P}$ were given a significantly higher amount of feed compared to that of the other farms during the blind feeding period (one way ANOVA, $\mathrm{p}<0.05$ ). The average weight of shrimp after the blind feeding period did not correlate to the feed amount given during the same time period (Pearson correlation, $\mathrm{R}=-0.33 ; \mathrm{p}=0.6$ ).

Table 2. Feed amounts given in selected shrimp farms during the blind feeding period

\begin{tabular}{llllll}
\hline Farm & M1 & T1 & M2 & T2 & P \\
\hline $\begin{array}{l}\text { Total feed } \\
\text { given }(\mathrm{kg} /\end{array}$ & $126.8^{\mathrm{ab} \pm 40}$ & $198.9^{\mathrm{ac}} \pm 20$ & $120.84^{\mathrm{b}} \pm 24$ & $131.5^{\mathrm{ab}} \pm 9$ & $219.8^{\mathrm{c}} \pm 10$ \\
$10^{5}$ pls) & & & & \\
$\begin{array}{l}\text { Feeding rate } \\
\text { (kg/day/ha) }\end{array}$ & $9.45^{\mathrm{ab} \pm 2.1}$ & $14.7^{\mathrm{c}} \pm 2.6$ & $8.3^{\mathrm{b}} \pm 1.4$ & $9.74^{\mathrm{a}} \pm 2.7$ & $16.23^{\mathrm{c}} \pm 3.8$ \\
& & & & & \\
\hline
\end{tabular}


Values with different superscript are significantly different from each other (One way ANOVA using Scheffe'e comparison of means; $\mathrm{p}<0.05)$; pls - post larvae No correlation was found between the amount of feed given with the initial stocking densities of shrimp post larvae during the blind feeding period. Farm M2 with the highest stocking $\left(30 \mathrm{pls} / \mathrm{m}^{2}\right)$ had the lowest feeding rate.

Figure 2. Fluctuation of mean feed given with respect to stocking density during the blind feeding period against initial stocking densities of shrimp post larvae

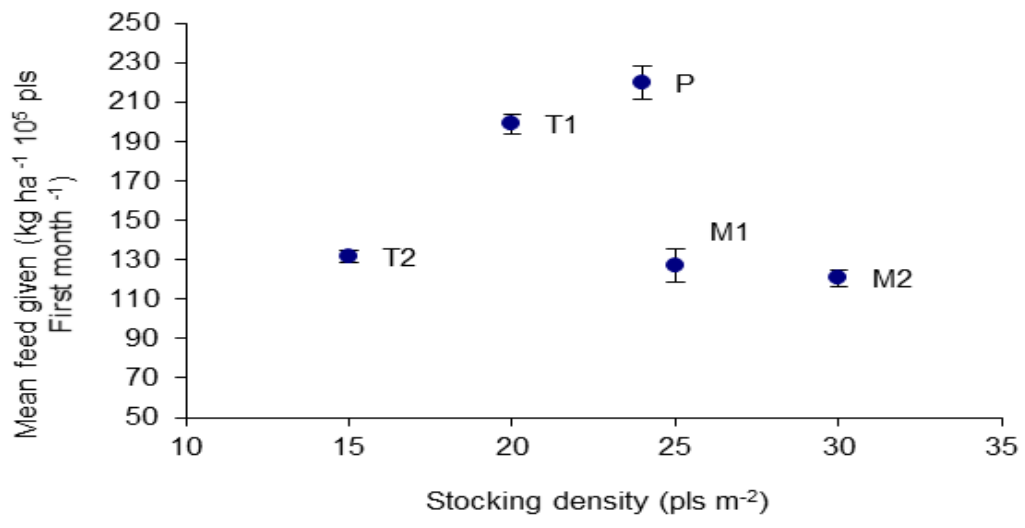

The mean percentage SGR day ${ }^{-1}$ of shrimp (Figure 3) varied between 2.9 - 3.5 and it did not have a correlation with feed amount given during the same period (Pearson correlation, $\mathrm{R}=-0.15 ; \mathrm{p}=0.8$ ). 
Figure 3. Mean percentage SGR day ${ }^{-1} \pm S D$ of shrimp against feed amount given during the blind feeding period in each selected farm

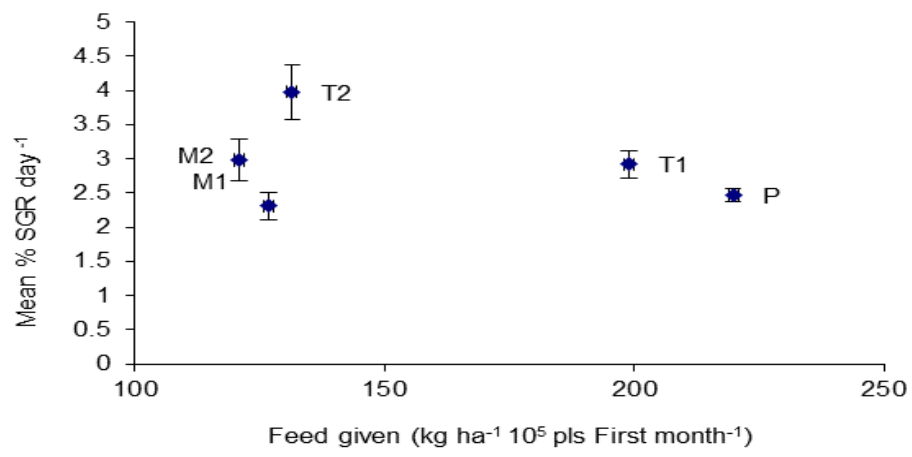

\section{Pond water quality}

The dissolved oxygen, $\mathrm{pH}$ value, salinity, temperature, ammonia and nitrate concentrations in experimental pond water were not significantly different (Oneway ANOVA, p>0.05). Significantly higher turbidity levels were observed in pond water in farms $\mathrm{T} 1$ and $\mathrm{P}$ while significantly lower nitrite levels were observed in farms M1 and T2 (Oneway ANOVA, p<0.05). Significantly lower phosphorus levels in pond water were detected in farms M2 and T2 (One way ANOVA, $\mathrm{p}<0.05)$.

Table 3. Mean \pm sd of physico-chemical parameters during the blind feeding period in shrimp culture ponds

\begin{tabular}{|c|c|c|c|c|c|}
\hline Parameter & Farm M1 & Farm T1 & Farm M2 & Farm T2 & Farm P \\
\hline DO (mg/l) & $4.4^{\mathrm{a}} \pm 1.2$ & $4.0^{\mathrm{a}} \pm 0.3$ & $5.1^{\mathrm{a}} \pm 0.4$ & $4.4^{\mathrm{a}} \pm 0.3$ & $4.8^{\mathrm{a}} \pm 0.7$ \\
\hline $\mathrm{pH}$ & $7.9^{\mathrm{a}} \pm 0.3$ & $8.0^{\mathrm{a}} \pm 0.3$ & $7.9^{\mathrm{a}} \pm 0.1$ & $8.4^{\mathrm{a}} \pm 0.2$ & $8.3^{\mathrm{a}} \pm 0.1$ \\
\hline \multirow[t]{2}{*}{ Salinity (ppt) } & $24.8^{\mathrm{a}} \pm 0.7$ & $25.5^{\mathrm{a}} \pm$ & $25.2^{\mathrm{a}} \pm$ & $23.7^{\mathrm{a}} \pm 1.5$ & $26.4^{\mathrm{a}} \pm$ \\
\hline & & 0.7 & 1.2 & & 2.4 \\
\hline
\end{tabular}




\begin{tabular}{|c|c|c|c|c|c|}
\hline $\begin{array}{l}\text { Turbidity } \\
\text { (NTU) }\end{array}$ & $17.5^{\mathrm{a}} \pm 4.1$ & $26.8^{\mathrm{b}} \pm 1.5$ & $16.2^{\mathrm{a}} \pm 6.4$ & $16.7^{\mathrm{a}} \pm 1.1$ & $28.1^{\mathrm{b}} \pm 5.3$ \\
\hline $\begin{array}{l}\text { Temperature } \\
\left(\mathrm{C}^{\circ}\right)\end{array}$ & $28.4^{\mathrm{a}} \pm 0.8$ & $30.1^{\mathrm{a}} \pm 0.5$ & $30.6^{\mathrm{a}} \pm 0.3$ & $29.7^{a} \pm 1.1$ & $\begin{array}{l}28.1^{\mathrm{a}} \pm \\
0.6\end{array}$ \\
\hline $\begin{array}{l}\text { Ammonia } \\
(\mathrm{mg} / \mathrm{l})\end{array}$ & $0.18^{a} \pm 0.0$ & $\begin{array}{l}0.099^{\mathrm{a}} \pm \\
0.0\end{array}$ & $\begin{array}{ll}0.09 & \mathrm{a} \quad \pm \\
0.0 & \end{array}$ & $0.19^{\mathrm{a}} \pm 0.0$ & $\begin{array}{l}0.17 \quad \mathrm{a} \quad \pm \\
0.0\end{array}$ \\
\hline Nitrite $(\mu \mathrm{g} / 1)$ & $\begin{array}{l}16.1^{\mathrm{ab}} \quad \pm \\
9.1\end{array}$ & $20.5^{\mathrm{a}} \pm 6.3$ & $20.7^{\mathrm{a}} \pm 6.7$ & $14.0^{\mathrm{b}} \pm 3.6$ & $24.5^{\mathrm{a}} \pm 3.7$ \\
\hline $\begin{array}{l}\text { Nitrate } \\
(\mathrm{mg} / \mathrm{l})\end{array}$ & $0.21^{\mathrm{a}} \pm 0.1$ & $0.18^{\mathrm{a}} \pm 0.6$ & $0.16^{\mathrm{a}} \pm 0.1$ & $0.13^{\mathrm{a}} \pm 0.2$ & $0.25^{\mathrm{a}} \pm 0.7$ \\
\hline $\begin{array}{l}\text { Phosphorus } \\
(\mathrm{mg} / \mathrm{l})\end{array}$ & $1.4^{\mathrm{a}} \pm 0.14$ & $\begin{array}{l}0.9^{\mathrm{a}} \pm \\
0.30\end{array}$ & $\begin{array}{ll}0.3 \quad \mathrm{~b} \quad \pm \\
0.10\end{array}$ & $0.3^{\mathrm{b}} \pm 0.07$ & $\begin{array}{l}1.2^{\mathrm{a}} \pm \\
0.24\end{array}$ \\
\hline
\end{tabular}

Means with different superscripts in each row are significantly different $(\mathrm{p}<0.05)$ as determined by oneway ANOVA followed by Tukey's pair wise comparison of means.

\section{Discussion}

In all the farms supplementary feed was given from the time of stocking irrespective of the quantity of fertilizer used and/ or natural food availability. The farmers did not have a methodology to assess the natural food availability in culture ponds and also there is no standard method to calculate the ration size during the initial stages of the culture cycle. Samocha and Lawrence (1992) suggested to calculate the daily feed requirement of post larval to juvenile shrimp based on a $\mathrm{kg} / \mathrm{ha} / \mathrm{day}$ basis rather than on the biomass of the shrimp. The feeding rates in shrimp culture ponds with $24-30 \mathrm{pls} / \mathrm{m}^{2}$ ranged from $8-16 \mathrm{~kg} / \mathrm{ha} / \mathrm{day}$ in the present study. The feeding rate in nursery ponds of another widely cultured shrimp species, $P$. vannamei at a stocking density of $150-200 \mathrm{pls} / \mathrm{m}^{2}$ were 13.1 $\mathrm{kg} / \mathrm{ha}$ /day in Ecuador (calculated according to Duenas et al., 1983). Accordingly, during this study young $P$. monodon seemed to be over fed by the farmers.

Although some of the water quality parameters significantly varied among farms they were within the optimum ranges for cultured shrimp according to Poernemo, 
(1990); therefore, those variations of water quality might not have a significant impact on shrimp larval growth or feed consumption during time period of the present study. Water quality deterioration during the initial stages of farming cannot be expected as the stocked animals are small and their metabolism rate and amounts of supplementary feed given are low (Tseng et al., 1998).

The lack of correlation between SGR\% of shrimp with the amount of feed given indicates the importance of the availability of natural food for the growth of post larval shrimp. The availability of benthos and other food organisms may have significantly contributed to the growth of shrimp during the initial stage of the culture cycle (Rulbright \& Harvell, 1981; Anderson et al., 1987; Cook \& Clifford, 1997; Shishehchian \& Yusoff, 1999). However, the contribution of natural pond productivity to the nutrition of shrimp decreased as stocking density increased (Apud et al., 1980; Maguire and Leedow, 1983). Farm T2 with the lowest stocking density $\left(15 \mathrm{pls} / \mathrm{m}^{2}\right)$ recorded the highest \%SGR (3.9/day) during the blind feeding period. This farm was fertilized using cow dung and chicken manure, and this practice might have increased the natural productivity in the pond. Shrimp are opportunistic feeders and are able to harness food particles suspended in the water column (e.g. phytoplankton, zooplankton, microbial flocs, organic detritus, etc.) and food organisms living in the bottom of the pond (e.g. plant and animal biota), in addition to the formulated feeds provided (Robertson et al., 1993; Nunes, 2009). Therefore, adding large quantities of high valued nutritious feed without giving due consideration to natural productivity of culture water is a waste of resources and should be minimized in semi-intensive shrimp culture.

It is obvious that there is no acceptable method for determining the initial feeding rates. Farmers believe excess feed used during the initial stages of the culture cycle would help to promote the algal bloom in pond water. The use of expensive nutritious feed as a fertilizer is questionable environmentally and economically. It is important to train the young shrimp to accept formulated feed for the expected fast growth at later stages and therefore the availability of sufficient formulated feed could be essential in intensively managed ponds. According to Qingyin et al. (1995) Chinese shrimp farmers provide little or no feed at the first few weeks in 
semi intensive shrimp culture ponds and this practice could be recommended for Sri Lankan shrimp farms that are managed under semi-intensive systems.

The feed intake pattern and consumption rate of shrimp varies widely under different agro-climatic conditions (Tacon et al., 2013; Hung \& Quy, 2013). Therefore, a site specific standardized feeding program is essential for effective feed management (Mohanty, 2001). The results of this study could be used to prepare guidelines for such on farm feed management strategies for semiintensively managed P. monodon grow-out ponds in the North West of Sri Lanka.

\section{References:}

Akiyama, D. M., Chwang, N. L. M. 1989. Shrimp feed requirement and feed management. Proceedings of the Southeast Asia shrimp farm management workshop. (Ed. D. E. M. Akiyama). Baton Range, LA, USA. p.198-205.

Anderson, R. K., P. L. Paeker, A. A. Lawrence. 1987. A 13C/12C tracer study of the utilization of presented feed by a commercially important shrimp $P$. vannmei in a pond grow out system. Journal of the World Aquaculture Society 18(3).p.148155.

Apud, F. D., Deatras, N., Gonzales, K. G. 1980. Feeding behaviour and food preferences of Penaeus monodon with scrap tilapia. Southeast Asian Fisheries Development Centre, Aquaculture Department. Quarterly Research Publication. 4(3) 19-21.

Cook, H. L. and H. C. Clifford. 1997. Feed management for semi intensive shrimp culture: part 1 - Initial feeding. Aquaculture Magazine. p.1: 30-42.

Cruz, P. S. 1991. Shrimp feeding management, Principles and Practices. Kabukiran Enterprises, Inc. Dovao City, Philippines. p.1-51.

De Silva, S. S., Davy F. B. 1992. Strategies for finfish nutrition in research for semi-intensive aquaculture in Asia. Asian Fisheries Science. 5.129-144.

Duenas, J. A. Harmsen and C. Emberson. 1983. Penaeid shrimp culture in Ecuador. Proceedings of the First International Conference on warm water 
aquaculture - Crustacea (Eds. G. L. Rogers, R. day and A. Lim). Brigham Young University, Laie, Hawaii, USA. p.99-108.

Hasan, M. R. 2001. Nutrition and feeding for sustainable aquaculture development. In Aquaculture in the Third Millenium. (Eds. R. P. Subasinghe, P. Bueno, M. J. Phillips, C. Hough, S. E. McGladdery and J. R. Arthur). Technical Proceedings of the Conference on Aquaculture in the Third Millenium. Bankok, Thailand. p.193-220.

Hung, L.T. and Quy, O.M. 2013. On farm feeding and feed management in whiteleg shrimp (Litopenaeus vannamei) farming in Viet Nam. In M.R. Hasan and M.B. New, eds. On-farm feeding and feed management in aquaculture. FAO Fisheries and Aquaculture Technical Paper No. 583. Rome, FAO. pp. 337-357.

Jorry, D. E. 1995. Feed management practices for a healthy pond environment. Swimming through troubled water. Proceedings of the special session on shrimp training, Aquaculture '95. (Eds. C. L. Crowdly and J. S. Hopkins). World Aquaculture Society, Louisiana, USA. p.118-137.

Maguire, G. B., M. I. Leedow. 1983. A study of the optimum stocking density and feed rate for school prawns Metapenaeus macleay (Haswell) in some Australian brackish water farming ponds. Aquaculture 30.p.285-297.

Mohanty, R. K. 2001. Feeding management and waste production in semi intensive farming of Penaeus monodon at different stocking densities. Aquaculture International 9:345 - 355.

Nunes, A. J. P., Parsons, G. J. 1999. Feeding levels of the southern brown shrimp Penaeus subtilis in response to food dispersal. Journal of the world Aquaculture society. 30(3):331- 348 .

Nunes, A.J.P. 2009. Overview on the contribution of natural food items to shrimp growth in aquaculture ponds. Book of Abstracts, XI Congresso Ecuatoriano de Acuiculture \& AquaExpo AQUA, pp. 48-50. Guayaquil, Cámara Nacional de Acuacultura.

Parsons, T. R., Maita, Y., Lalli, C. M. 1984. A manual of chemical and biological methods for seawater analysis. Pergamon Press, Oxford. p.682. 
Poernemo, A. 1990. Site selection for coastal shrimp ponds. In: Technical and economical aspects of shrimp farming. (eds. M.B. New, H. de Saram and T. Singh), pp. 3-20. AQUA TECH conference, KulaLampur, Malaysia.

Qingyin, W., Y. Conghai, Y. Jia. 1995. The shrimp industry in China: Past development, present status and Perspectives on the future. Swimming through troubled water. Proceedings of the special session on shrimp training, Aquaculture '95.World Aquaculture Society, Louisiana, USA. p.1-12.

Robertson, L., Lawrence, A. L., Castille, F. L. 1993. Effect of feeding frequency and feeding time on growth of Penaeus vannamei (Boone). Aquaculture and Fisheries Management. 24: 1-6.

Rulbright, J. S., Harell, J. L. 1981. Responses of planktonic and benthic communities to fertilizer and feed applications in shrimp aquaculture ponds. World aquaculture 12 (1).p. 289 - 299.

Samocha, T. M. and L. A. Lawrence. 1992. Shrimp nursery systems and management. Proceedings of the Special Session on shrimp farming. World Aquaculture Society, Baton Rouge, LA, USA. p.87 - 105.

Shishehchian, F. and Yusoff, F. M. 1999. Composition and abundance of macro benthos in intensive tropical marine shrimp culture ponds. World Aquaculture 30 (1):128 - 133 .

Tacon, A. G. J. 1993. Feed formulation and on farm feed management. Proceedings of the FAO/ AADCP Regional Expert Consultation on farm made aqua feeds. Bangkok, Thailand. p.61 - 74.

Tacon, A.G.J., Jory, D. \& Nunes, A. 2013. Shrimp feed management: issues and perspectives. In M.R. Hasan and M.B. New, eds. On-farm feeding and feed management in aquaculture. FAO Fisheries and Aquaculture Technical Paper No. 583. Rome, FAO. pp. 481-488.

Tseng, K. F., Su, Huei, M. \& Su, M. S. 1998. Culture of Penaeus monodon in a recirculation system. Aquacultural Engineering. 17: 138-147. 